Article

\title{
Overview of Safety Measures at Selected Airports during the COVID-19 Pandemic
}

\author{
Monika Blišt anová $(\mathbb{D}$, Michaela Tirpáková * (1) and L'ubomíra Brůnová
}

Department of Air Traffic Management, Faculty of Aeronautics, Technical University of Košice, 040-01 Košice, Slovakia; monika.blistanova@tuke.sk (M.B.); lubomira.brunova@tuke.sk (L'B.)

* Correspondence: michaela.tirpakova@tuke.sk

check for updates

Citation: Blišt'anová, M.; Tirpáková, M.; Brůnová, L'. Overview of Safety Measures at Selected Airports during the COVID-19 Pandemic.

Sustainability 2021, 13, 8499. https:// doi.org/10.3390/su13158499

Academic Editors: Armando Cartenì and Ilaria Henke

Received: 29 June 2021

Accepted: 28 July 2021

Published: 29 July 2021

Publisher's Note: MDPI stays neutral with regard to jurisdictional claims in published maps and institutional affiliations.

Copyright: (c) 2021 by the authors. Licensee MDPI, Basel, Switzerland. This article is an open access article distributed under the terms and conditions of the Creative Commons Attribution (CC BY) license (https:/ / creativecommons.org/licenses/by/ $4.0 /)$.

\begin{abstract}
The year 2020 was very challenging for the whole world, given the outbreak of the ongoing coronavirus-related pandemic, and was marked in particular by overcoming new hitherto unknown obstacles. For air transport, in particular, airlines stopped flying altogether and were forced to ground hundreds of planes worldwide involuntarily. Airports had to close their terminals for a long time, wholly suspend operations, and its resumption required significant organizational changes. This article summarizes the measures related to the COVID-19 pandemic adopted by airports to minimize the risk of spreading the disease. The article focuses on countermeasures and their implementation at selected airports in a specific time frame and airports' behavior during a pandemic which varies depending on country and time of the year. The results demonstrated that steps being taken at airports include the use of face coverings or masks, social distance, enhanced cleaning and disinfection, or temperature checks and/or symptoms (fever, loss of smell, chills, cough, shortness of breath), RT-PCR (reverse transcription-polymerase chain reaction) screening and data collection with health declaration. These measures have now become an essential standard for the operation of airports and can, therefore, be used to assess the level of airport safety achieved. In the final phase, the article evaluates the level of achieved airport safety based on the proposed scoring method.
\end{abstract}

Keywords: safety; safety measures; pandemic; airports

\section{Introduction}

Since early cases were identified in Wuhan, China, at the end of December 2019, coronavirus disease 2019 (COVID-19), caused by the severe acute respiratory syndrome coronavirus 2 (SARS-CoV-2), has been spreading rapidly [1,2]. The outbreak of COVID-19 was declared a pandemic by the World Health Organization (WHO) on March 11 2020, and now it is considered global, with significant autochthonous transmission in different countries [3]. The virus that causes COVID-19 is released, primarily in droplets that can be propelled a short distance away and in smaller aerosol particles that can stay suspended and move further. If these particles enter a person's mouth or nose, either directly or through hands, another person may be infected. In some cases, transmission via surface contact is also probable $[4,5]$. According to the WHO, it takes 5- 6 days after being infected for symptoms to become visible. The common symptoms are fever, cough, tiredness and headache [6]. The WHO declared Europe the epicenter of the latest 2019 coronavirus pandemic on March 13 2020, with more confirmed cases and deaths than the rest of the globe combined. As the novel coronavirus pandemic spread worldwide in March 2020, travel restrictions were introduced in many European countries and worldwide [7]. Nations worldwide have adopted various approaches to handle arising issues. States have used travel bans, the closure of borders (lockdowns) and restrictions on people's mobility to reduce the virus's spread [8]. Europe took various mobility containment measures to control the spread of COVID-19. The main reason is that mobility data at the EU scale can improve knowledge of the dynamics of the pandemic and probably 
limit the result of future waves [9]. Tourist mobilities helped COVID-19 become a global pandemic. Due to mobilities being a proper theoretical framing where positions tourism is a part of everyday life, the disease spread so quickly [10]. According to the study by the authors of [11], the relationship between positive COVID-19 cases and transport accessibility of an area was investigated within a multiple linear regression model. The estimation outcomes reveal that transportation accessibility was the variable that better described the number of COVID-19 infections, indicating that the larger the accessibility of a particular geographic area, the easier the virus reaches its population. The COVID-19 pandemic has also impacted air transport mobility internationally and the airline industry in general. Numerous airline travel restrictions have been imposed, potentially leading to significant long-term effects on the global airline industry [12]. Aviation is one of the industries that has been experiencing most problems due to the results of the pandemic outbreak, despite apparently being one of its most significant initial drivers [13]. However, most studies demonstrated that contracting COVID-19 during air travel is lower than from an office, classroom, supermarket, or train. Air travel might appear such as the ideal way for COVID-19 transmission: it carries many people into a limited space, often for hours at a time. However, many modern aircraft have great high-efficiency particulate air (HEPA) filters that catch more than 99 per cent of particles in the air, including microbes as SARSCoV-2 [14]. However, being in a plane and flying might not even be the most dangerous part of travel. According to studies $[15,16]$ the more hazardous part is staying at the airport. Airports are potentially dangerous places for swapping microbes. They're closed in, with no open windows and a high concentration of people, especially during peak hours. The crisis has forced the aviation industry (especially airports) to adapt to the situation quickly. With many aircraft grounded due to a substantial decrease in passenger demand, the civil aviation authorities, airlines and airports try to find alternate, quick and effective measures to survive as the crisis continues worldwide [17]. While the pandemic could not be entirely stopped, air travel partly returned to service, and passengers could use airline services during the summer of 2020. It was conditional on strict hygiene and health measures being followed, not only onboard the aircraft but also at the airports. It was essential to realize that stopping the disease worldwide can be ensured by appropriate measures already at the airport. There is a high concentration of passengers and, at the same time, if an infected case boards the aircraft, measures are often unnecessary. Passengers are exposed to a much higher risk of infection. Nevertheless, most research concentrates directly on the flight and transmission of the virus onboard the aircraft or the overall impact caused by the pandemic, with little mention of the spread of the virus at airports or the adoption of measures. There are various national and international strategies or recommendations that allow and help adapt to the situation. However, the truth is that they differ significantly, and what applies at one airport may not be of use at an airport in a neighboring state. It is precisely this fact that may raise the question of how safe individual airports are. Public health measures aim to prevent the person-to-person spread of disease by separating people to interrupt transmission. The used tools are isolation and quarantine, social distancing and community containment. All these tools are being applied at an unprecedentedly large scale $[18,19]$. Preventive measures are the primary approach to limit the spread of cases. Still, unless these measures are already taken at the airport, there is a high probability that an infected passenger will board the aircraft. The most fundamental strategy is to wear face masks, constantly wash hands, use compact hand sanitizer and avoid touching the face and mouth after interacting with a probably contaminated environment. Although the first wave of the COVID-19 pandemic proceeded more slowly, the second wave appeared much more aggressive, with many more cases [20]. A relaxation of lockdowns and the public's loosening of precautionary behaviors during summer 2020 has seen recorded cases and deaths rise across Europe [21]. As the second wave emerged in the rapidly spreading disease and many infected people, there is an essential requirement for efficient infection prevention and control measures. Even though the second (August-September 2020) and third waves (November 2020-present) began with growing social activity with 
lower social distancing, the spread was decreased successfully by the rapid strengthening of social distancing policies through the initial stages. Despite considerable numbers of studies [22-24] there is still only limited evidence assessing anti-pandemic measures for air travel or everyday life.

\section{Theoretical Background}

Airports had to adjust to the new requirements and measures arising from the adopted situation. It entered into force in the May 2020 Doc 10144 ICAO Handbook for Civil Aviation Authorities (CAAs) on the Management of Aviation Safety Risks related to COVID-19, the ICAO's response to the pandemic to prevent the spread of the virus and ensure the safe operation of air traffic. The ICAO developed the content with the support of aviation safety management experts. Addressing a pandemic situation requires cooperation and communication at international, national and regional levels. Given the very different levels of preparedness of states and potential future crises (including the new COVID-19 waves and mutation), it is crucial to work with them in the next decision. Identifying, collecting and analyzing data is essential in supporting the decision-making process related to assessing the situation within COVID-19. Monitoring the current situation helps in modelling scenarios to support risk management and better understand impacts. All aviation authorities are actively involved in the process of exchanging information and relevant resources. Collected data are used to ensure informatization, the risk management approach and support the development of recovery plans [25]. Through the Council's Aviation Recovery Task Force (CART), the ICAO has decided to partner with all Member States, international and regional organizations and the industry to address these challenges and provide global guidelines and guidelines for the safe operation and sustainable restart and the renewal of the aviation sector. Human mobility contributes to transmitting contagious (infectious) diseases that act as dangerous threats to global health. Undoubtedly, many countries regulate human mobility flows as part of their response plans. However, restrictions on human mobility are uncertain because of their negative economic impacts and the uncertainty about their effectiveness in controlling the epidemic [26,27]. Following the outbreak of the COVID-19 pandemic, all states, including government regulators, airports, airlines and aircraft manufacturers, have developed, in coordination with public health authorities, a set of measures to reduce the risk of the spread of the disease to passengers, aviation workers and the general public. These measures aim to reduce the risk of spreading the disease and contribute to safe air transport. Simultaneously, compliance with these measures is expected to facilitate and strengthen the global restart of air transport. The measures are divided into several modules for better management: airport, aircraft, personnel and cargo transport. The research was focused mainly on the measures in the airport module because the lockdown and the measures taken by the states have significantly affected airports, the functioning of airports and caused significant passenger losses and profits. The airport module contains specific elements addressing guidelines for the terminal building, ensuring cleanliness, disinfection and hygiene of airport areas, physical deployment and protection of personnel, check-in area, security control, gate installations, passenger transport and transfers and baggage claim [28]. The ICAO published a document [29] which presented a possible model for risk assessment. This model also includes a simple example of identifying the effectiveness of existing measures (Figure 1), which results from several studies. Both studies focused on the effectiveness of the measures they examined through specific simulation models. The first research [30] dealt with quarantines, recording the following results: quarantine period of 8 days on arrival with a PCR test on day 7 (with a 1-day delay for test results) can reduce the number of infectious arrivals released into the community by a median $94 \%$ compared to a no quarantine, no test scenario. This reduction is similar to that achieved by a 14-day quarantine period (median $99 \%$ reduction). The second research [31] dealt with quarantines and their effectiveness in a specific case in the UK. These studies were selected by the ICAO together with the public health authorities and the expert consensus as a model based on which the effectiveness of individual measures 
can be appropriately estimated. Effectiveness in this meaning is described as the degree to which the measure is expected to reduce the risk of introducing infectious individuals into the community at the destination.

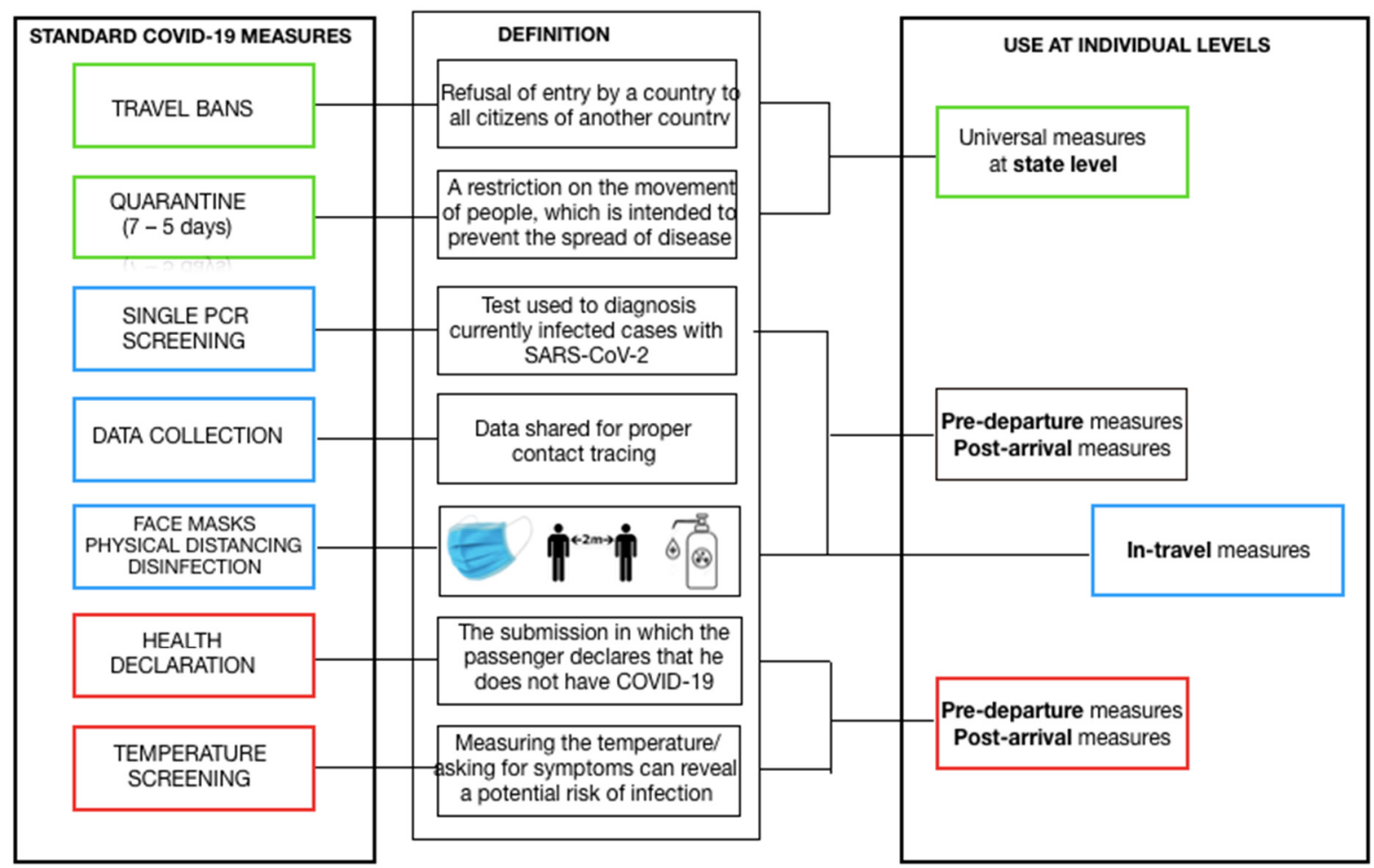

ESTIMATED EFFECTIVENESS

(Doc 10152)

HIGH MEDIUM LOW

Figure 1. Evaluation of standard COVID-19 measures according to their effectiveness (Doc 10152).

\section{Methodology}

The qualitative part of the research was aimed to collect data on topics related to air transportation during the pandemic in general and specifically at measures or recommendations adopted by airports associated with reducing COVID-19's spread. For the identification of related publications, a standardized search approach was used. The Web of Sciences, Scopus and Google Scholar databases were searched by applying the search terms "coronavirus", "COVID-19", "SARS-CoV-2", "pandemic", "aviation", "airport" in combinations with the words "measures", "recommendations", "face masks", "quarantine measures", "social distancing" and "testing". Supplementary sources of information were websites of the International Civil Aviation Organization (ICAO), International Air Transport Association (IATA) and Airports Council International (ACI) which provided information about air traffic volume and documents related to COVID-19 measures and recommendations for air transportation. The overview part of the research examined and summarized the application and use of the measures described to reduce the risk associated with the disease's possible spread to passengers, aviation workers and the general public. The overview results from a qualitative part of the research and thorough analysis and data collection during the monitored period at selected airports. The examined airports (Table 1) are important European transit points and were selected based on their direct or indirect flight connection with Slovakia, including Slovak airports. The result was a quality overview of applied measures, which pointed to signs of synthesis and understanding of the topic. This overview has evidence of analytical thinking shown through the connections between the literature being reviewed. 
Table 1. List of selected European airports according to their direct or indirect flight connection with Slovakia, including Slovak airports.

\begin{tabular}{cccc}
\hline State & Iata Code & Airport & $\begin{array}{c}\text { Lockdowns/Travel } \\
\text { Bans }\end{array}$ \\
UK & LHR & London Heathrow & $\checkmark$ \\
France & CDG & Paris Charles de Gaulle airport & $\checkmark$ \\
Germany & FRA & Frankfurt am Main Airport & $\checkmark$ \\
Spain & MAD & Madrid-Barajas Airport & $\checkmark$ \\
Germany & MUC & Munich Airport & $\checkmark$ \\
Italy & FCO & Fiumicino International Airport & $\checkmark$ \\
Ireland & DUB & Dublin Airport & $\checkmark$ \\
Austria & VIE & Vienna International Airport & $\checkmark$ \\
Poland & WAW & Warsaw Chopin Airport & $\checkmark$ \\
UK & LTN & London Luton Airport & $\checkmark$ \\
Czech Republic & PRG & Václav Havel Airport Prague & $\checkmark$ \\
Hungary & BUD & Budapest Ferenc Liszt Inter. Airport & $\checkmark$ \\
Ukraine & IEV & Igor Sikorsky Kyiv Inter. Airport & $\checkmark$ \\
Slovakia & BTS & Bratislava Airport & $\checkmark$ \\
Slovakia & KSC & Košice International Airport & $\checkmark$ \\
Poland & LUZ & Lublin Airport & $\checkmark$ \\
Germany & BER & Berlin Brandenburg Airport & \\
\hline
\end{tabular}

Official airports' websites were checked to evaluate adopted measures and changes at airports, reactions to the pandemic and its development through measures according to the specificities of the airport and applicable national legislation and subsequent implementation by secondary sources. Searched keywords were "COVID-19 information", "passenger information", "safe travel", "airport measures" and "safety innovations". In the observed period from late October to turn of the year 2020/2021 changes at airports were monitored, their reactions to the pandemic and its development through measures according to the specificities of the airport and applicable national legislation and their subsequent implementation by secondary sources [32-48] (official airports' websites and various internet resources). The monitored period was divided into three phases for better research results:

- $\quad$ Starting point (phase one): post-summer to late November 2020;

- Phase two: turn of the year 2020/2021;

- Phase three: acquisition of standard measures and final scoring.

The research focused mainly on anti-pandemic measures adopted by nations (lockdowns and travel bans) and airports, including social distancing, wearing face masks or other protective equipment to cover the upper and lower airways and ensuring proper disinfection at airports. The analysis also dealt with testing at airports or measuring temperature, providing online information for passengers with data collection close contacts in infected cases. It should be added that this information (in particular, data collection) was difficult to find during the research because neither airports nor European organizations publish this information (unlike, for example, USA). These data were monitored weekly in connection with the countries' current situation and the number of newly infected cases. For research needs, the method of scoring individual measures (Figure 2) was chosen, thanks to which it was possible to assess airports in the conclusion of the research. A point scale from 1 to 5 points was chosen, with each measure being assigned a score based on effectiveness (Doc 10152). The whole principle of scoring consists of setting the relevant (based on Doc 10152) points to individual measures and, in total, the airport can have 20 points. Based on these points, the airport can be at the safety level, a very high (15-20 points), high (11-15 points), moderate (6-10 points) and low level (0-5 points). Travel Bans and Quarantine were considered the most effective measures ( 5 points) because they are strictly regulated by the state and prevent the free movement of people and passengers between countries and different continents. Therefore, the risk of infection is low and new types 
of virus mutations do not occur. Single PCR Screening and Data Collection (3 points) are mainly justified for ensuring flight safety, as potentially infected passengers were detected before entering the airport. Information on these cases is available immediately. Unfortunately, this information is no longer provided. It does not disclose what constitutes a limitation of this article, for instance, if it would be necessary to determine the number of infected cases directly at airports. Given that the wearing of face masks, disinfection and physical distancing have become a general standard, they will be considered as 2 points for this article. On the other hand, depending on the effectiveness of individual measures, those measures related to temperature measurement were considered the least influential (1 point) because the elevated temperature can result from several aspects in humans, and health declarations can be kind or untrue even though it is mandatory for every airport.
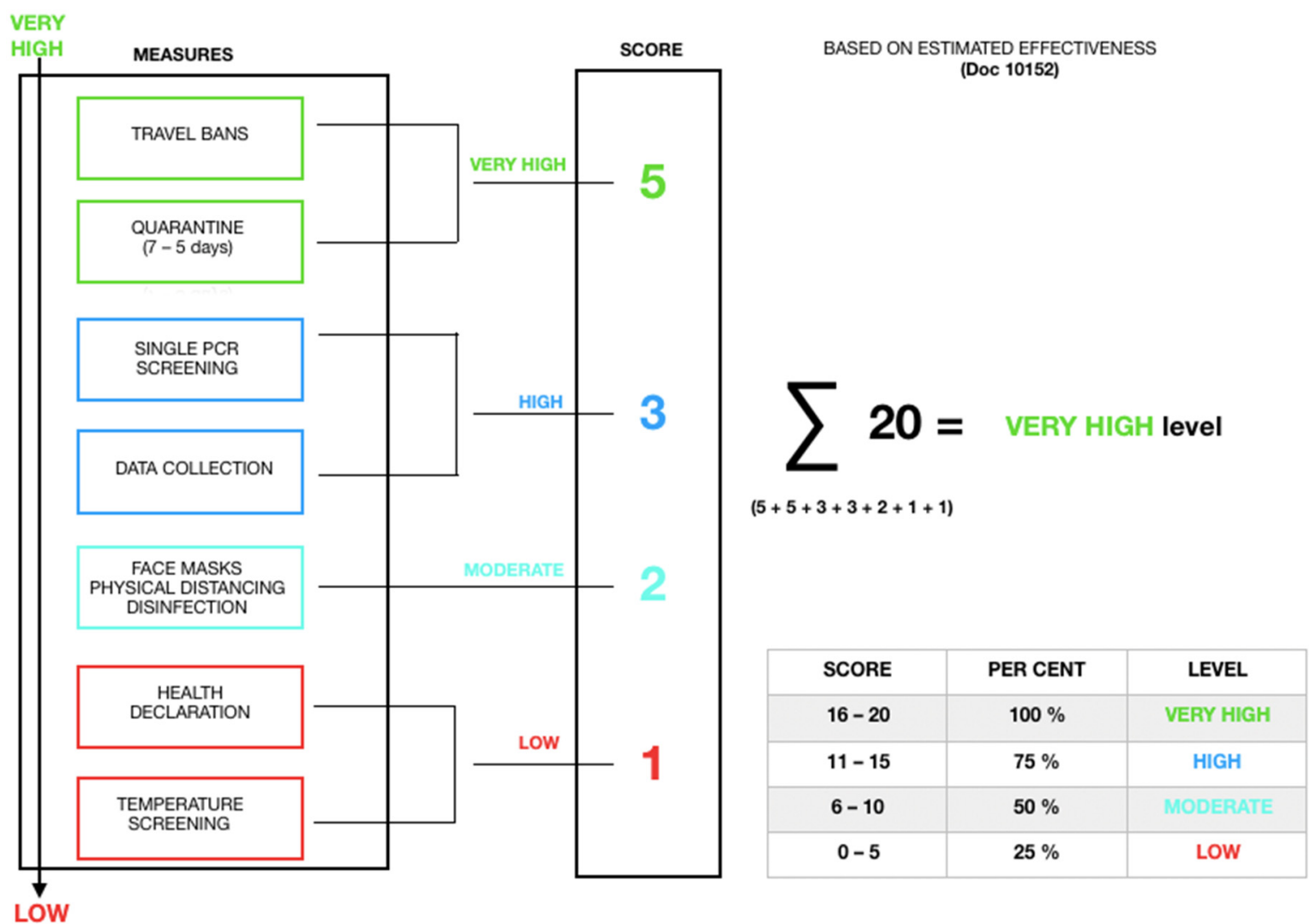

Figure 2. A proposed scoring method based on the effectiveness of individual measures, in the point range of 1-5.

\section{Results}

Regular monitoring was chosen for a complete and comprehensive understanding of airports' measures and their implementation and changes. The results (Tables 2 and 3) expressly pointed to the differences in adaptation between the separate weeks at the selected airports. For better research conclusions, the whole monitored period was divided into three main phases. The starting point was post Summer to late November, and the second phase was in the turn of the year 2020/2021. Both of these phases were affected by significant changes in people's behavior. The starting point was characterized by the end of a more relaxed summer period with the onset of more stringent measures and the beginning of massive testing by antigen or RT-PCR (reverse transcription-polymerase chain reaction) tests. The second phase directly reflects the beginning of the new year, at the same time, the holiday season, which is characterized by a significant increase in human movement. The third phase represents the permanent adoption of individual measures as a constant standard and emphasizes the need and development of new, more adaptive measures. 
Table 2. Evaluation of implemented measures in the period of post summer to late November 2020 (the starting point).

\begin{tabular}{ccccccc}
\hline Airport & $\begin{array}{c}\text { Social Distance } \\
\text { < 2 m }\end{array}$ & $\begin{array}{c}\text { Face } \\
\text { Masks }\end{array}$ & Disinfection & $\begin{array}{c}\text { Temperature } \\
\text { Check }\end{array}$ & $\begin{array}{c}\text { Rt-PCR } \\
\text { Screening }\end{array}$ & Score \\
\hline LHR & $\checkmark$ & $\checkmark$ & $\checkmark$ & $\checkmark$ & PARTLY & 14.5 \\
CDG & $1.5 . \mathrm{M}$ & $\checkmark$ & $\checkmark$ & $\checkmark$ & PARTLY & 14.5 \\
FRA & $1.5 . \mathrm{M}$ & $\checkmark$ & $\checkmark$ & NO & $\checkmark$ & 15 \\
MAD & $1.5 . \mathrm{M}$ & $\checkmark$ & PARTLY & PARTLY & NO & 11.5 \\
MUC & $1.5 . \mathrm{M}$ & $\checkmark$ & $\checkmark$ & NO & $\checkmark$ & 15 \\
FCO & $1 \mathrm{M}$ & $\checkmark$ & $\checkmark$ & $\checkmark$ & $\checkmark$ & 16 \\
DUB & $\checkmark$ & $\checkmark$ & PARTLY & PARTLY & PARTLY & 13 \\
VIE & $\checkmark$ & $\checkmark$ & $\checkmark$ & $\checkmark$ & $\checkmark$ & 16 \\
WAW & $1.5 \mathrm{M}$ & $\checkmark$ & $\checkmark$ & PARTLY & NO & 12.5 \\
LTN & $\checkmark$ & $\checkmark$ & $\checkmark$ & NO & $\checkmark$ & 13 \\
PRG & $\checkmark$ & $\checkmark$ & $\checkmark$ & PARTLY & NO & 15 \\
BUD & $1.5 \mathrm{M}$ & PARTLY & PARTLY & $\checkmark$ & $\checkmark$ & 15 \\
IEV & PARTLY & $\checkmark$ & $\checkmark$ & $\checkmark$ & NO & 13 \\
BTS & $\checkmark$ & $\checkmark$ & $\checkmark$ & $\checkmark$ & NO & 13 \\
KSC & $\checkmark$ & $\checkmark$ & $\checkmark$ & $\checkmark$ & $\checkmark$ & 13 \\
LUZ & $1.5 \mathrm{M}$ & $\checkmark$ & $\checkmark$ & NO & $\checkmark$ & 15 \\
BER & $\checkmark$ & $\checkmark$ & $\checkmark$ & & & \\
\hline
\end{tabular}

Table 3. Evaluation of implemented measures in the period of turn of the year 2020/2021 (phase 2).

\begin{tabular}{ccccccc}
\hline Airport & $\begin{array}{c}\text { Social Distance } \\
\text { < 2 m }\end{array}$ & $\begin{array}{c}\text { Face } \\
\text { Masks }\end{array}$ & Disinfection & $\begin{array}{c}\text { Temperature } \\
\text { Check }\end{array}$ & $\begin{array}{c}\text { Rt-PCR } \\
\text { Screening }\end{array}$ & Score \\
\hline LHR & $\checkmark$ & $\checkmark$ & $\checkmark$ & $\checkmark$ & $\checkmark$ & 16 \\
CDG & $\checkmark$ & $\checkmark$ & $\checkmark$ & $\checkmark$ & $\checkmark$ & 16 \\
FRA & $\checkmark$ & $\checkmark$ & $\checkmark$ & NO & $\checkmark$ & 15 \\
MAD & $\checkmark$ & $\checkmark$ & $\checkmark$ & $\checkmark$ & NO & 13 \\
MUC & $\checkmark$ & $\checkmark$ & $\checkmark$ & NO & $\checkmark$ & 15 \\
FCO & $1 \mathrm{M}$ & $\checkmark$ & $\checkmark$ & $\checkmark$ & $\checkmark$ & 16 \\
DUB & $\checkmark$ & $\checkmark$ & $\checkmark$ & $\checkmark$ & $\checkmark$ & 16 \\
VIE & $\checkmark$ & $\checkmark$ & $\checkmark$ & $\checkmark$ & $\checkmark$ & 16 \\
WAW & $\checkmark$ & $\checkmark$ & $\checkmark$ & $\checkmark$ & $\checkmark$ & 16 \\
LTN & $\checkmark$ & $\checkmark$ & $\checkmark$ & NO & $\checkmark$ & 13 \\
PRG & $\checkmark$ & $\checkmark$ & $\checkmark$ & $\checkmark$ & NO & 13 \\
BUD & $\checkmark$ & $\checkmark$ & $\checkmark$ & $\checkmark$ & 16 \\
IEV & $1.5 \mathrm{M}$ & $\checkmark$ & $\checkmark$ & $\checkmark$ & NO & 13 \\
BTS & $\checkmark$ & $\checkmark$ & $\checkmark$ & $\checkmark$ & NO & 13 \\
KSC & $\checkmark$ & $\checkmark$ & $\checkmark$ & $\checkmark$ & 13 \\
LUZ & $1.5 \mathrm{M}$ & $\checkmark$ & $\checkmark$ & & 15 \\
BER & $\checkmark$ & & $\checkmark$ & & $\checkmark$ & \\
\hline
\end{tabular}

At the beginning of the research, it was possible to see the weakening of the summer season and the application of minimal measures due to the summer. Many airports applied minor measures, which did not correspond to the growing number of infected cases, which led to a gradual increase in mobility and a greater spread of the disease. The results showed (Table 2) that airports gradually began to apply the necessary measures in part with the increasing number of infected daily cases. Although some airports had a social distance of up to $2 \mathrm{~m}$, some airports applied social distancing at $1.5 \mathrm{~m}$ and only $1 \mathrm{~m}$. Additionally, Madrid Airport only used the need to wear protective masks. Dublin Airport did not carry out the necessary disinfection of the areas. Only nine airports (Heathrow, Paris, Rome, Vienna, London-Luton-, Kyiv, Bratislava, Kosice and Lublin) measured temperature. The tests were performed only in Frankfurt, Munich, Rome, Vienna, Prague, Kyiv and Berlin. France allowed travel only for necessary and work reasons from late October and only with the French government's permission. The airports slowly changed 
the need for a social distance to $2 \mathrm{~m}$. It has been mandatory to wear face masks at each airport. Thorough disinfection of areas and the gradual installation of plexiglass and other protective equipment was used. Airports also started with temperature checks, and a new test sites were added. In general, airports having an obligation to prove a negative antigen or RT-PCR test came into force, even for the actual entrance to the terminal building. All measures applied at almost all airports. Some airports were considering suspending all flights. Given that each country had applied massive lockdowns and quarantine since the starting point, the measures were not implemented to the same extent at all airports. Based on the research scoring method, it is possible to observe the most significant point differences between airports in the starting point of the research. The airports with a very high safety level were considered to be Vienna Airport and the airport in Rome, Italy, with a total of 16 points, which, in addition to the application of a lockdown (5 points) and quarantine (5 points), the sum of 10 points, introduced other measures, namely, social distancing, face masks and disinfection ( 2 points), temperature checks (1 point) and RT-PCR screening (3 points). On the contrary, the airport with a safety level "high" (in this case with the lowest points score) was considered to be the airport Budapest (sum of 11 points in total), which was unable to react flexibly to the situation and measures taken, which were also signed on the insufficient amount of information on the official website.

Although the number of infected people was still rising, Rome Airport was easing measures and introducing a social gap of only one meter. Budapest Airport started to strengthen its measures compared to the previous phase significantly, and Slovak airports resumed all flights. Vienna Airport came up with an innovative and affordable solution. The so-called "COVID premium service" offered passengers an RT-PCR test, express equipment together with the airport staff and a protective set (gloves, drape, disinfection) in one package. Before Christmas, airlines significantly strengthened routes at almost all airports. All airports were subject to a strict regime and nearly all measures. This is because it is at this time of the year that the movement of people increases significantly. By applying and, to some extent, tightening up these measures, airports have sought to ensure air safety and, thus, maintain a particular capacity of passengers. The temperature was not measured in Frankfurt, Munich and Berlin (all German airports) and Prague. It was not tested directly at Madrid, London-Luton-, Budapest, Kosice, Bratislava and Lublin. The finding was that the one-week interval showed only minimal changes in the airports' measures. Simultaneously, the number of infected cases increased again, and the pandemic fell into the so-called third wave. The results for the turn of the year 2020/2021 (Table 3) indicated that the airports already took permanent measures, monitoring in the previous period. With the growing number of infected cases worldwide, airports had to implement measures that significantly strengthened their safety level. Thus, there was a significant increase in their points when the scoring method was applied. Compared to the starting point, where the safety level "very high" had only two airports, this level reached up to seven airports, $41 \%$ of all examined. The lower number of points was mainly due to the absence of RT-PCR screening.

As the results showed (Table 4), airports took all measures (social distancing, wearing face masks, complete disinfection, temperature checks and testing) as a generally applicable standard. Others also started to be used for these measures, e.g., data collection (3 points) which supports the informatization of national governments on the movement of persons and a health declaration (1 point) based on which passengers declared their health, possible overcoming of the virus and other necessary health information. The preliminary assessment of airports showed only a minimal difference between their points. Thus, most airports remained at the safety level "high", which ultimately represented a relatively good pandemic readiness. However, the final assessment, after adding the other two complementary measures, changed the situation significantly. Still, it appeared that those airports that had the highest number of points in the preliminary assessment, even after adding these measures, still had the highest number of points. Thus, they achieved almost $100 \%$ scores and the safety level "very high". On the contrary, airports with fewer 
points (but still in the safety level "very high") in the preliminary evaluation reached a maximum of $85 \%$ of the total number of points. This is mainly because these airports still do not perform RT-PCR screening or have not included other complementary measures in their standards.

Table 4. Acquisition of standard measures and final scoring with the permanent score and total score (phase 3).

\begin{tabular}{|c|c|c|c|c|c|}
\hline Airport & $\begin{array}{l}\text { Preliminary } \\
\text { Score }\end{array}$ & $\begin{array}{c}\text { Data } \\
\text { Collection }\end{array}$ & $\begin{array}{c}\text { Health } \\
\text { Declaration }\end{array}$ & Total Score & Percent \\
\hline LHR & 16 & $\checkmark$ & NO & 19 & $95 \%$ \\
\hline CDG & 16 & $\checkmark$ & $\checkmark$ & 20 & $100 \%$ \\
\hline FRA & 15 & $\checkmark$ & $\checkmark$ & 19 & $95 \%$ \\
\hline MAD & 13 & $\checkmark$ & $\checkmark$ & 17 & $85 \%$ \\
\hline MUC & 15 & $\checkmark$ & $\mathrm{NO}$ & 18 & $90 \%$ \\
\hline FCO & 16 & $\checkmark$ & $\checkmark$ & 20 & $100 \%$ \\
\hline DUB & 16 & $\checkmark$ & $\checkmark$ & 20 & $100 \%$ \\
\hline VIE & 16 & $\checkmark$ & $\checkmark$ & 20 & $100 \%$ \\
\hline WAW & 16 & $\checkmark$ & $\mathrm{NO}$ & 19 & $95 \%$ \\
\hline LTN & 13 & $\checkmark$ & $\checkmark$ & 17 & $85 \%$ \\
\hline PRG & 15 & $\checkmark$ & $\checkmark$ & 19 & $95 \%$ \\
\hline BUD & 13 & $\checkmark$ & $\checkmark$ & 17 & $85 \%$ \\
\hline IEV & 16 & $\checkmark$ & $\checkmark$ & 20 & $100 \%$ \\
\hline BTS & 13 & $\checkmark$ & $\checkmark$ & 17 & $85 \%$ \\
\hline KSC & 13 & $\checkmark$ & $\checkmark$ & 17 & $85 \%$ \\
\hline LUZ & 13 & $\checkmark$ & $\checkmark$ & 19 & $85 \%$ \\
\hline BER & 15 & $\checkmark$ & $\checkmark$ & 19 & $95 \%$ \\
\hline
\end{tabular}

Based on the performed research, it is also possible to evaluate the individual phases (Figure 3) and assess their relative state from the safety perspective.

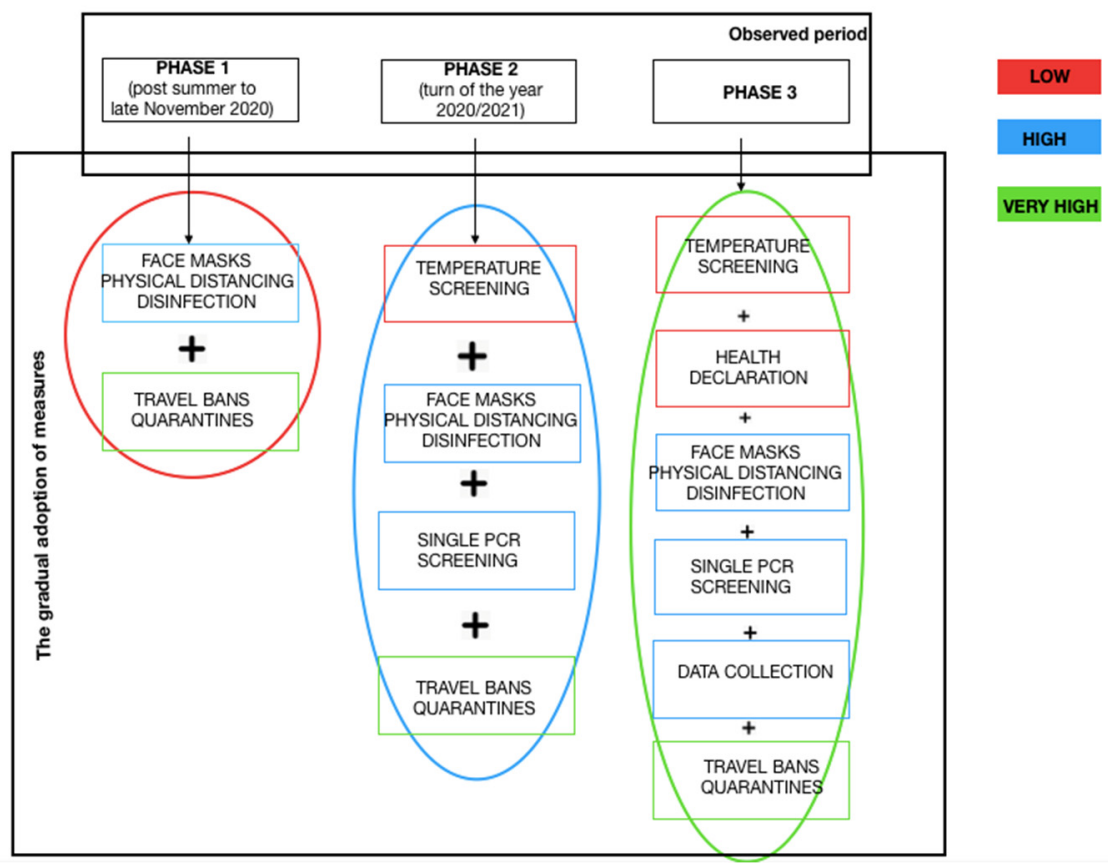

Figure 3. Evaluation of individual phases with regard to the applied measures and evaluation of their effectiveness.

The starting point (phase 1 in the figure)—post-summer until November 2020-could be evaluated based on the measures taken as a phase where the approach was not completely sufficient with minimal measures. The main reason was the end of the summer 
season, which increased the mobility of the population. This period was not marked by strict measures consisting mainly of mandatory quarantines and a massive testing of people arriving from abroad, which is currently the standard. Thus, it was possible to observe marked differences between the first and the currently set standards and approaches to pandemics.

Phase 2-turn of the year 2020/2021-was to be relative with the safety level "high" because airports took measures that became a safe standard, and their use can still be observed today. Lessons learned from the previous period, and in connection with the rapid increase in the number of cases during the summer months, at the turn of 2020/2021, states decided to tighten measures that already began to include mandatory quarantines after arrival from abroad or full-scale lockdowns.

The last phase of the research emphasized adopting all measures, including quarantines, which could only be interrupted by a negative RT-PCR test. It can be noted that the importance of the test results was mainly conditioned by the increasing new variants and mutations of coronavirus. Airports aimed to ensure and guarantee passengers the safest possible travel and minimize the negative economic impacts.

At the same time, the research made it possible to assess the safety of individual airports (Figure 4), considering the measures taken, the degree of response to the pandemic and the stage at which the measures were taken. As all airports took standard steps in a relatively fast time, it was not entirely possible to talk about airports that would be dangerous to passengers, even if passengers were detained at the airport for a long time.

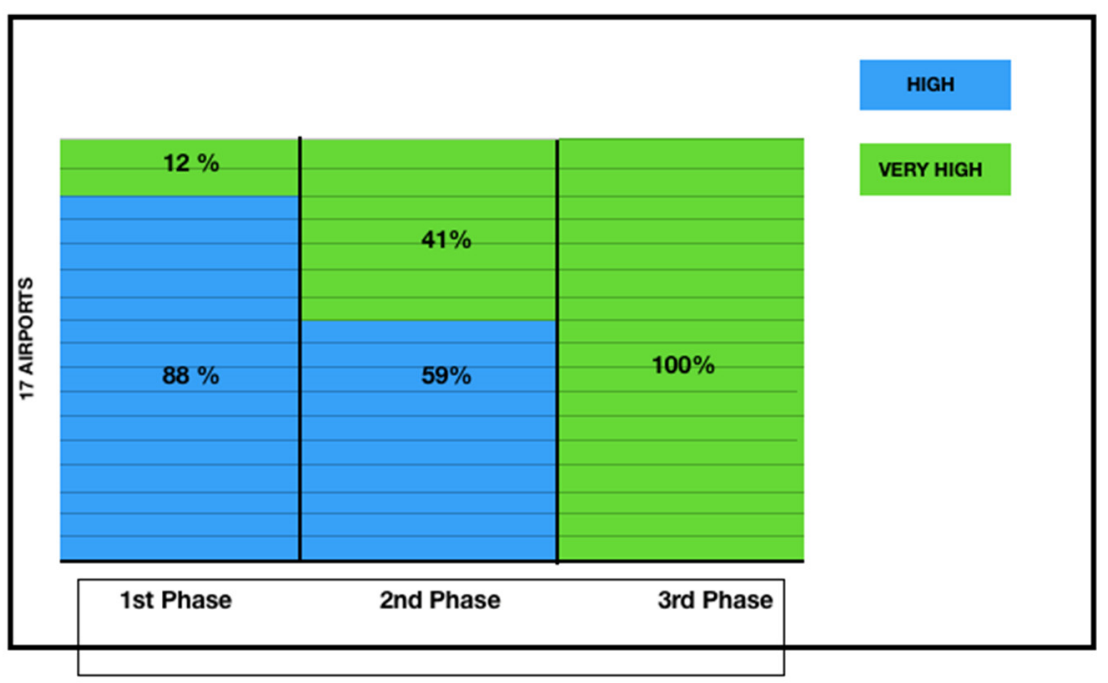

Figure 4. Graphic evaluation of individual phases and percentage expression of airport success in terms of implemented safety measures.

The graph (Figure 4) was used to demonstrate the results of this research, which was divided into three phases. Each phase was method-specific and different from the next. At the starting point, $88 \%$ of all airports were at the "high" level and only $12 \%$ at the "very high" level. In contrast, the second phase already brought a significant improvement, which can be seen in the fact that up to $41 \%$ of airports, in this case, were at the level of "very high", which was $29 \%$ more than at the starting point. The last phase was already $100 \%$, all airports implemented the monitored measures, and, thus, reached the level of "very high". The "low" or "moderate" level did not appear in any phase of the research.

\section{Conclusions}

The year 2020 can be described as an exceptional year, but rather in the negative sense of the word. The ICAO recently published its 4th edition of the World Civil Aviation Report [49], evaluating its work in tackling the challenges posed by the COVID-19 pandemic and its impact on the aviation industry. The research aimed to record changes in the imple- 
mentation of anti-pandemic measures at individually selected airports in the monitored period from late October 2020 to the turn of 2020/2021. The airports were chosen based on direct or indirect flight connections with Slovakia and essential transit airports in Europe. The first part of this research focused on determining the theoretical basis that defined and described the legislation adopted in the selected area and anti-pandemic measures adopted worldwide. These anti-pandemic measures are currently already considered the standard in the fight against the spread of COVID-19. The results show that the situation changed rapidly since the time of year, which of course has contributed to the tightening of regional, national and international measures. The research was carried out at regular intervals, and in particular, information was found on the measures and how individual airports approached this pandemic and ensured safe travel. This research was based on the proposed scoring method, thanks to which it was possible to assess airports in the research conclusion. A point scale from 1 to 5 points was adopted, with each measure being assigned a score based on effectiveness (Doc 10152). Based on these points, the airport could be at the safety level very high (15-20 points), high (11-15 points), moderate (6-10 points) and low (0-5 points).

The start of the research was marked mainly by the gradual end of the summer and, thus, the measures were partially or entirely relaxed. Changes began to occur in phase 2, which, in contrast to the starting point, changed significantly and, for example, a new phenomenon of mass testing was introduced. The third phase of the research specifically compared the observed period and, based on the evaluation, awarded points according to a set scoring method. In addition to testing, data collection began on passengers who had to complete a health declaration or similar forms. It can be stated that the pandemic brought with it many changes, which significantly affected the desire of passengers to continue travelling. The last step of the research focused on the overall evaluation of phases and the assessment of airports according to what measures they took in the monitored period. To sum up, it is possible to see that there are no longer airports that would be downright dangerous at present, but it can distinguish between airports that are safer more or less. All examined airports reached the highest level of safety, "very high" in the last phase.

Limitations: Of course, this research has many limitations related, for example, to the continuous development of the situation, to changes in international standards and national measures taken. The article has certain limitations also because some information is quite challenging to find. In particular, it concerns information on the overall effectiveness of the measures in practice and, for instance, directly on how many infected cases have been detected at the airport (based on data collection or health declaration). Specifically, for the selected region, as no European organization or airports provide these data. Interestingly, the USA's Transportation Security Administration (TSA) provides such information and updates it regularly. By way of example only [50], 407 positive cases have been confirmed at JFK-John F. Kennedy International Airport (as of 15 July 2021) - , of which only 26 were airport employees. In this example, we can see that awareness and access to information differ depending on the region and country. However, it should not be forgotten that although the application of individual measures and their effectiveness is relatively high (based on previous research), this may not mean immediate good results for practice.

In conclusion, it is possible to say that air traffic has been hit hard by the COVID-19 pandemic, particularly at airports. Still, airports can tighten safety and hygiene standards very quickly and effectively in a deteriorating epidemiological situation. Measures such as the use of face masks or respirators, social distance, improved cleaning and disinfection, temperature and symptoms checks can be considered the future and an irreplaceable part of safe travel. Even though the pandemic persists, airports can cope with such a situation and take steps that minimize the spread of the disease. Although each state regulates these rules itself, exchanging information, they share their experiences and inspire each other to adopt new best practices. 
Author Contributions: Conceptualization, M.B., M.T. and L'.B.; data curation, M.T. and L'.B.; methodology, M.B., M.T. and L'.B.; supervision, M.B.; resources, M.T. and L'.B.; writing-original draft preparation, M.B., M.T. and L'.B.; writing—review and editing, M.B., M.T. and L'.B. All authors have read and agreed to the published version of the manuscript.

Funding: This article is part of project New possibilities and Approaches of Optimization within Logistic Processes in the field of Transport and Transport Systems, ITMS code: 313011T567, and supported by the project Mobile Monitoring System for the Protection of Isolated and Vulnerable Population Groups against Spread of Viral Diseases, ITMS code 313011AUP1, co-funded by the European Regional Development Fund under the Operational Programme Integrated Infrastructure.

Institutional Review Board Statement: Not applicable.

Informed Consent Statement: Not applicable.

Data Availability Statement: Not applicable.

Conflicts of Interest: The authors declare no conflict of interest.

\section{Abbreviations}

\begin{tabular}{|c|c|}
\hline RT-PCR & Reverse transcription polymerase chain reaction \\
\hline COVID-19 & Coronavirus disease 2019 \\
\hline SARS-CoV-2 & Severe acute respiratory syndrome coronavirus 2 \\
\hline $\mathrm{WHO}$ & World Health Organization \\
\hline $\mathrm{ICAO}$ & International Civil Aviation Organization \\
\hline CAAs & Civil Aviation Authorities \\
\hline CART & Council's Aviation Recovery Task Force \\
\hline IATA & International Air Transport Association \\
\hline ACI & Airports Council International \\
\hline UK & United Kingdom \\
\hline LHR & London Heathrow \\
\hline CDG & Paris Charles de Gaulle airport \\
\hline FRA & Frankfurt am Main Airport \\
\hline MAD & Madrid-Barajas Airport \\
\hline MUC & Munich Airport \\
\hline $\mathrm{FCO}$ & Fiumicino International Airport \\
\hline DUB & Dublin Airport \\
\hline VIE & Vienna Airport \\
\hline WAW & Warsaw Chopin Airport \\
\hline LTN & London Luton Airport \\
\hline PRG & Václav Havel Airport Prague \\
\hline BUD & Budapest Ferenc Liszt Inter. Airport \\
\hline IEV & Igor Sikorsky Kyiv Inter. Airport \\
\hline BTS & Bratislava Airport \\
\hline KSC & Košice International Airport \\
\hline LUZ & Lublin Airport \\
\hline BER & Berlin Brandenburg Airport \\
\hline USA & United States of America \\
\hline TSA & Transport Security Administration \\
\hline
\end{tabular}

\section{References}

1. Huang, C.; Wang, Y.; Li, X.; Ren, L.; Zhao, J.; Hu, Y.; Zhang, L.; Fan, G.; Xu, J.; Gu, X.; et al. Clinical features of patients infected with 2019 novel coronavirus in Wuhan, China. Lancet 2020, 395, 497-506. [CrossRef]

2. Holshue, M.L.; DeBolt, C.; Lindquist, S.; Lofy, K.H.; Wiesman, J.; Bruce, H.; Spitters, C.; Ericson, K.; Wilkerson, S.; Tural, A.; et al. First case of 2019 novel coronavirus in the United States. N. Engl. J. Med. 2020, 382, 929-936. [CrossRef]

3. World Health Organization. WHO Director-General's Opening Remarks at the Media Briefing on COVID-19. 2020. Available online: https:/ / www.who.int/dg/speeches/detail/who-director-general-s-opening-remarks-at-the-mission-briefing-on-covid19-13-march (accessed on 20 December 2020).

4. Pombal, R.; Hosegood, I.; Powell, D. Risk of COVID-19 during air travel. JAMA Patient Page 2020, 324, 1798. 
5. Wölfel, R.; Corman, V.M.; Guggemos, W.; Seilmaier, M.; Zange, S.; Müller, M.A.; Niemeyer, D.; Jones, T.C.; Vollmar, P.; Rothe, C.; et al. Virological assessment of hospitalized patients with COVID-2019. Nature 2020, 581, 465-469. [CrossRef] [PubMed]

6. Kumar, V.; Doshi, K.U.; Khan, W.H.; Rathore, A.S. COVID-19 pandemic: Mechanism, diagnosis and treatment. J. Chem. Technol. Biotechnol. 2020, 96, 299-308. [CrossRef]

7. Lytras, T.; Dellis, G.; Flountzi, A.; Hatzianastasiou, S.; Nikolopoulou, G.; Tsekou, K.; Diamantis, Z.; Stathopoulou, G.; Togka, M.; Gerolymatos, G.; et al. High prevalence of SARS-CoV-2 infection in repatriation flights to Greece from three European countries. J. Travel Med. 2020, 27, taaa054. [CrossRef]

8. Goniewicz, K.; Khorram-Manesh, A.; Hertelendy, A.J.; Goniewicz, M.; Naylor, K.; Burkle, F.M. Current response and management decisions of the European Union to the COVID-19 outbreak: A review. Sustainability 2020, 12, 3838. [CrossRef]

9. Iacus, S.M.; Santamaria, C.; Sermi, F.; Spyratos, S.; Tarchi, D.; Vespe, M. Human mobility and COVID-19 initial dynamics. Nonlinear Dyn. 2020, 101, 1901-1919. [CrossRef] [PubMed]

10. Iquanto, B.L. Tourist as vector: Viral mobilities of COVID-19. Dialogues Hum. Geogr. 2020, 10, 174-177. [CrossRef]

11. Cartenì, A.; Francesco, D.L.; Martino, M. The role of transport accessibility within the spread of the Coronavirus pandemic in Italy. Saf. Sci. 2021, 133, 104999. [CrossRef]

12. Nižetić, S. Impact of coronavirus (COVID-19) pandemic on air transport mobility, energy, and environment: A case study. Int. J. Energy Res. 2020, 44, 10953-10961. [CrossRef]

13. Sun, X.; Wandelt, S.; Zhang, A. How did COVID-19 impact air transportation? A first peek through the lens of complex networks. J. Air Transp. Manag. 2020, 89, 101928. [CrossRef]

14. Bushwich, S.; Lewis, T.; Montanez, A. Evaluating COVID Risk on Planes, Trains and Automobiles. Available online: https: //www.scientificamerican.com/article/evaluating-covid-risk-on-planes-trains-and-automobiles2/ (accessed on 28 March 2021).

15. Nakamura, H.; Managi, S. Airport risk of imporation and exportation of the COVID-19 pandemic. Transp. Policy 2020, 96, 40-47. [CrossRef]

16. Daon, Y.; Thompson, N.R.; Obolski, U. Estimating COVID-19 outbreak risk through air travel. J. Travel Med. 2020, 27, taaa093. [CrossRef]

17. Serrano, F.; Kazda, A. The future of airport post COVID-19. J. Air Transp. Manag. 2020, 89, 101900. [CrossRef]

18. Wilder-Smith, A.; Freedman, D.O. Isolation, quarantine, social distancing and community containment: Pivotal role for old-style public health measures in the novel coronavirus (2019-nCoV) outbreak. J. Travel Med. 2020, 27, 1-4. [CrossRef]

19. Güner, H.R.; Hasanoğlu, I.; Aktaş, F. COVID-19: Prevention and control measures in community. Turk. J. Med. Sci. 2020, 50, 571-577. [CrossRef] [PubMed]

20. Salyer, S.J.; Maeda, J.; Sembuche, S.; Kebede, Y.; Tshangela, A.; Moussif, M.; Ihekweazu, C.; Mayet, N.; Abate, E.; Ouma, A.O.; et al. The first and second waves of the COVID-19 pandemic in Africa: A cross-sectional study. Lancet 2021, 397, 1265-1275. [CrossRef]

21. Looi, M.K. Covid-19: Is a second wave hitting Europe? BMJ 2020, 371, m4113. [CrossRef]

22. Bielecki, M.; Patel, D.; Hinkelbein, J.; Komorowski, M.; Kester, J.; Ebrahim, S.; Rodriguez-Morales, A.J.; Memish, Z.A.; Schlagenhauf, P. Reprint of: Air travel and COVID-19 prevention in the pandemic and peri-pandemic period: A narrative review. Travel Med. Infect. Dis. 2020, 38, 101939. [CrossRef]

23. Chu, D.K.; Akl, E.A.; Duda, S.; Solo, K.; Yaacoub, S.; Schünemann, H.J.; El-harakeh, A.; Bognanni, A.; Lotfi, T.; Loeb, M.; et al. Physical distancing, face masks, and eye protection to prevent person-to-person transmission of SARS-CoV-2 and COVID-19: A systematic review and meta-analysis. Lancet 2020, 395, 1973-1987. [CrossRef]

24. Xiao, Y.; Torok, M.E. Taking the right measures to control COVID-19. Lancet Infect. Dis. 2020, 20, 523-524. [CrossRef]

25. International Civil Aviation Organization (ICAO). Doc. 10144 ICAO Handbook for CAAs on the Management of Aviation Safety Risks related to COVID-19. 2020. Available online: https://www.icao.int/safety/SafetyManagement/Doc10144/Doc\%2010144 pdf (accessed on 13 January 2021).

26. Fang, H.; Wang, L.; Yang, Y. Human mobility restrictions and the spread of the Novel Coronavirus (2019-nCoV) in China. J. Public Econ. 2020, 191, 104272. [CrossRef]

27. Cartenì, A.; Di Francesco, L.; Martino, M. How mobility habits influenced the spread of the COVID-19 pandemic: Results from the Italian case. Sci. Total Environ. 2020, 741, 140489. [CrossRef] [PubMed]

28. Hoang, A.T.; Nižetić, S.; Olcer, A.I.; Ong, H.C.; Chen, W.H.; Chong, C.T.; Thomas, S.; Bandh, S.A.; Nguyen, X.P. Impacts of COVID-19 pandemic on the global energy system and the shift progress to renewable energy: Opportunities, challenges, and policy implications. Energy Policy 2021, 154, 112322. [CrossRef]

29. International Civil Aviation Organization (ICAO). Doc. 10152 ICAO Manual on Testing and Cross-border Risk Management Measures. 2020. Available online: https:/ / www.icao.int/safety/CAPSCA/PublishingImages/Pages/ICAO-Manuals/Doc\% 2010152_Unedited\%20Second\%20Edition_Manual\%20on\%20Testing\%20and\%20Cross-border\%20Risk\%20Management\%20 Measures.PDF (accessed on 16 January 2021).

30. Clifford, S.; Quilty, B.J.; Russell, T.W.; Liu, Y.; Chan, Y.W.D.; Pearson, C.A.; Eggo, R.M.; Endo, A.; Flasche, S.; Edmunds, W.J.; et al. Strategies to reduce the risk of SARS-CoV-2 re-introduction from international traveller. medRxiv 2020. [CrossRef]

31. Taylor, R.; McCarthy, C.A.; Patel, V.; Moir, R.; Kelly, L.; Snary, E. The risk of introducing SARS-CoV-2 to the UK via international travel in August 2020. medRxiv 2020. [CrossRef]

32. Heathrow. Coronavirus Update. 2021. Available online: https://www.heathrow.com/customer-support/faq/coronavirus-covid19 (accessed on 20 March 2021). 
33. Paris Aéroport. Covid-19: Informations aux Voyageurs. 2021. Available online: https:/ www.parisaeroport.fr/passagers/lesvols / covid-19-informations-voyageurs (accessed on 20 March 2021).

34. Franfurt Airport. Informationen zu Covid-19. Unbesorgt Reisen ab Frankfurt Airport. 2021. Available online: https://www. frankfurt-airport.com/de/reisevorbereitung/coronavirus.html (accessed on 20 March 2021).

35. Skytrax. Madrid Barajas Airport COVID-19 Rating. 2021. Available online: https://skytraxratings.com/airports/madrid-barajasairport-covid-19-rating (accessed on 20 March 2021).

36. Munich Airport. Travelling in Times of the Coronavirus Pandemic. 2021. Available online: https:/ / www.munich-airport.com/ travelling-in-times-of-the-coronavirus-pandemic-8395611 (accessed on 20 March 2021).

37. Aeroporti di Roma. Covid-19. 2021. Available online: https://www.adr.it/it/web/guest/coronavirus (accessed on 20 March 2021).

38. Vienna Airport. Restricted Operation at Vienna Airport. 2021. Available online: https://www.viennaairport.com/en/passengers (accessed on 2 April 2021).

39. Warsaw Chopin Airport. Szybkie Testy w Kierunku COVID-19 dla Pasażerów Lotniska Chopina w Warszawie. 2021. Available online: https: / lotnisko-chopina.pl/pl/aktualnosci-i-wydarzenia/0/1018/szczegoly.html (accessed on 2 April 2021).

40. Dublin Airport. COVID-19 Safety Measures. 2021. Available online: https://www.dublinairport.com/covid-19/COVID19safety-measures (accessed on 2 April 2021).

41. London Luton. Safer Travel. 2021. Available online: https://www.london-luton.co.uk/safer-travel (accessed on 2 April 2021).

42. Prague Airport. Current Information and Recommendation for Passengers. 2021. Available online: https://www.prg.aero/en\#/ (accessed on 2 April 2021).

43. Budapest Airport. Covid-19: Információ az Utasok Részére. 2021. Available online: https://www.bud.hu/covid_19 (accessed on 2 April 2021).

44. Kyiv Sikorsky Airport. COVID-19 Safety Regulations. 2021. Available online: https://iev.aero/en/covid (accessed on 2 April 2021).

45. Bratislava Airport. Covid-19: QandA. 2021. Available online: https://www.bts.aero/covid-19-otazky-a-odpovede/ (accessed on 2 April 2021).

46. Kosice Airport. Informácie a Obmedzenia v Súvislosti s COVID-19. 2021. Available online: https://www.airportkosice.sk/sk/ pre-cestujucich/aktuality/informacie-obmedzenia-v-suvislosti-s-covid-19 (accessed on 2 April 2021).

47. Lublin Airport. Lublin Airport. 2021. Available online: https://www.airport.lublin.pl/en/ (accessed on 2 April 2021).

48. Berlin Airport. Flying Sagely under Corona Conditions. 2021. Available online: https://ber.berlin-airport.de/en/flying/covid19.html (accessed on 2 April 2021).

49. International Civil Aviation Organization (ICAO). ICAO World Civil Aviation Report (WCAR), 4th ed.; ICAO: Montréal, QC, Canada, 2020.

50. Transport Security Administration. Coronavirus (COVID-19) Information. 2021. Available online: https://www.tsa.gov/ coronavirus (accessed on 20 July 2021). 